\title{
Innovative Work Behavior (IWB) in the Knowledge Intensive Business Services (KIBS) Sector in Malaysia: The Effect of Leader-Member Exchange (LMX) and Social Capital (SC)
}

\author{
Sethela June ${ }^{1} \&$ Yeoh Khar Kheng ${ }^{1}$ \\ ${ }^{1}$ College of Business, School of Business Management, Universiti Utara Malaysia, Sintok, Kedah, Malaysia \\ Correspondence: Sethela June, College of Business, School of Business Management, Universiti Utara Malaysia, \\ Sintok, Kedah, Malaysia. Tel: 60-4-928-7531.E-mail: sethela@uum.edu.my; sethelajune@yahoo.com
}

Received: August 22, $2013 \quad$ Accepted: November 10, $2013 \quad$ Online Published: December 29, 2013
doi:10.5539/ass.v10n2p172
URL: http://dx.doi.org/10.5539/ass.v10n2p172

\begin{abstract}
Today, innovation is no longer belongs to the research and development (R\&D) lab per se. In fact, innovation can be considered more of a product of the human creative mind with an inherent tacit knowledge. In order to be a successful knowledge-based economy, employees must continually be innovative. As such, this research which relates to innovation by and large will assist in creating better understanding of innovation from the behavioral perspective. In the context of business, innovation has long been embraced by organizations seeking to remain viable, effective and competitive in a dynamic business environment. Looking at the perspective of individual level innovation, this study seeks to examine whether employees' innovative work behavior (IWB) can be influenced by leader-member exchange (LMX) and the social capital (SC) in the knowledge intensive business services (KIBS) sector in Malaysia. Using questionnaire mail survey a total of 318 data was obtained from the knowledge workers of the Multimedia Super Corridor (MSC) status companies in Malaysia. The findings show that LMX and SC was significantly and positively related to IWB. The result also reveals that SC has a stronger influence on the IWB of employees as compared to LMX. Discussions and implications of the study are discussed.
\end{abstract}

Keywords: innovative work behavior, leader-member exchange, social capital, knowledge-intensive business services, knowledge worker

\section{Introduction}

Innovation has become a prerequisite in many knowledge based economy. As such many efforts have been carried out by the Ministry of Science, Technology and Innovation (MOSTI) of Malaysia in support of innovation existence. The existence of patents/invention in a country can be contributed by employee innovative work behavior (IWB) (Scott \& Bruce, 1994). The IWB is defined as a deliberate introduction and solicitation of ideas (either between individuals, groups or organization as a whole), processes, products or procedures that are relatively new to the unit of adoption, intended to benefit greatly, either the individuals, groups or the organization (West \& Farr, 1990). Nonetheless, Malaysia has a low number of patents as compared to other countries as recorded by the United States Patent and Trademark Office (USPTO). In 2004, there were only 92 patents secured by Malaysia which is much lesser than other Asian countries such as Korea $(4,428)$ and Taiwan $(5,938)$ while Singapore managed to obtain 449 patents (Kassim, 2009).

Instead of relying on the manufacturing sector in meeting the global competition, Malaysia needs to consider the business services sector as a strategy to enter into the global knowledge-based economy (Malaysian Institute of Economic Research (MIER), 2010). In line with this, in order to get closer to the benchmark of developed countries like the United Kingdom (UK), involvement in the knowledge intensive business services (KIBS) sector is seen as the answer. KIBS is defined as a form of service which entails economic activities that will give rise to the creation, accumulation or dissemination of knowledge (Miles et al., 1995). In the UK, the KIBS sector contributed roughly $20 \%$ of both the GDP and the employment while it made up approximately $14 \%$ of the country export (Economic Planning Unit (EPU), 2010). The KIBS and employee IWB are related simply because KIBS does not rely on research and development (R\&D) employees per se, but it is also organized around the potential of all employees (Bessant, 2003). In other words, the level of innovation will be greater if 
efforts been mobilized to have all the employees in the organization regardless of their positions to engage in an innovative behavior (Nystrom, 1990).

\subsection{Research Justifications}

The presence of KIBS in Malaysia is largely over-looked, under-theorized and under-documented (Jarman \& Chopra, 2008). In many academic literatures in Malaysia, common terms like service, trade, information technology, call center, facilities management, business process outsourcing, business and management consultancy, market research, engineering consultancy and Multimedia Super Corridor (MSC) had been widely used, but not KIBS which actually encompassed all the above terms in the more holistic and strategic manner (EPU, 2009). According to Jarman and Chopra (2008), the Malaysian economy in the post agricultural phase has been largely involved in a lower value-added activity in the manufacturing sector. It appears as if Malaysia is set to follow a similar path in the service sector, carving out a niche for itself in lower end service sector activities. Thus, it is necessary for Malaysia to undertake KIBS as a strategic and innovative service industry to cement the formation of Malaysia's national innovation ecosystem, as well as the new realm of research in Malaysian higher education. The nature of the KIBS sector implied that organizations must realize a continuous flow of innovations to ensure continuity and to keep up with economic development (Bilderbeek, Hertog, Marklund, \& Miles, 1998).

Many past researches attempted to identify the determinants of innovation in view of its significance. The innovation determinants were classified into three broad categories which comprised of individual, organizational and environmental factors (Damanpour, Szabat, \& Evan, 1989; Damanpour, 1991). According to Damanpour (1991), among the three categories, determinants related to individual factor have been found to be the most significant. At the individual level, knowledge workers play significant roles in the innovation process especially in the context of KIBS sector (Yeoh, Mahmood, \& June, 2013). Knowledge workers refer to those who possessed one of these qualifications such as a university degree (in any discipline) or a graduate diploma (multimedia/ICT) from a professional experience in multimedia; and a master's degree or higher in any discipline (Multimedia Development Corporation (MDEC), 1999). Therefore, any study on innovation in Malaysia, particularly at the individual level such as innovative work behavior will contribute immensely to the body of knowledge in enhancing the level of innovation in Malaysia. Ironically, even though, awareness about the importance of innovation and creativity to business activities existed, there seems to be insufficient research on these issues in Malaysia (Razmi \& Hazman, 2002; Meriam, 2006).

Additionally, previous researches in Malaysia on innovation also tend to be general in nature and see innovation in a broader context (e.g. Mohamed, 1995; Jantan, Nasurdin, \& Fadzil, 2003; Ishak, 2005; Khairuzzaman \& Majid, 2007; Idris, 2008; Ghani, Hussin, \& Jusoff, 2009; Ibrahim, Zolait, Subramanian, \& Ashtiani, 2009) but there is a lack of research particularly in the context of KIBS sector or had addressed the IWB of the knowledge workers in Malaysia. In terms of the variables understudied, even though past researches have shown that leader-member exchange (LMX) (e.g. Scott \& Bruce, 1994; Basu \& Green, 1997; Yukl, 2006) and social capital (SC) (e.g. Burt, 1992; Tovstiga, 1999; Lin, 2001) do have influences on the IWB of employees, those studies were carried out in abroad and not in the context of KIBS sector. Given the dynamism of the KIBS sector, this study aimed to examine whether there is a relationship between LMX and SC on the IWB of those employees serving in the KIBS sector in Malaysia and.

\section{Research Framework}

\subsection{Social Exchange Theory (SET) and Social Capital Theory (SCT)}

Given the dynamism of the human relationship, SET was built with the intention to better understand the human behavior (Homans, 1958). As such, social exchange is said to occur when two or more persons willfully engaging in activities that can either be rewarding or costly (Blau, 1964). Meanwhile the SCT is based on SET in which it states that the relation between individuals' working networks determines how far an individual can obtain information and power, and influence organizational changes. The social capital is essential for effective collective work and interpersonal coordination (Bolino et al., 2002). One of the most influential form of social capital in the organization can be referred to the shared norm in which when in existence, can lead to the subordination of the members' personal interest to the interests of the group (Coleman, 1990). Furthermore, the SC also requires an element of reciprocity among the members in line with the idea behind the SET. This study has therefore been underpinned by the SET and the SCT as shown in Figure 1. 


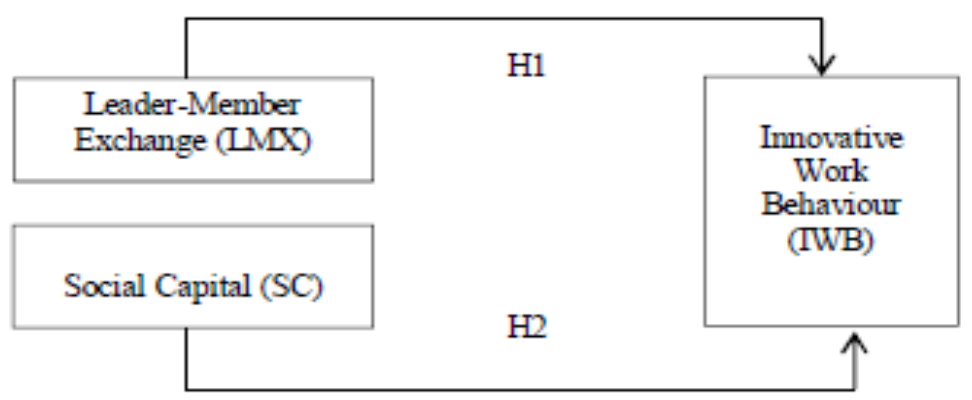

Figure 1. Research framework

In organizations, members are expected to repay the action that has been carried out on behalf of another member when the opportunity arises (Coleman, 1990). Thus, when individuals are able to identify themselves with a SC which is an important relational dimension, they will be more inclined towards establishing relationships that will provide them with the opportunity to exchange and combine resources (Nahapiet \& Ghoshal, 1998). These theories implied that employees will increase their loyalty, engagement, and work performance since they are obliged to return the act of kindness that they have received (Aselage \& Eisenberger, 2003). This will in turn make the employees obliged to take on the extra role behavior (Organ, 1988) which is important in seeding creativity and innovative behavior among the employees. The larger the obligation the greater it will exert the innovative work behavior on them (Blau, 1964).

\subsection{Innovative Work Behavior}

The characterization of innovation as a multistage process provides insight for the conceptualization of innovative work behavior used in this study. Literatures on innovation reveal some agreement that innovation is a multistage process (Kanter, 1988; Wheelwright \& Clark, 1995). Kanter's (1988) stage model of innovation is chosen in this because it specifically describes the work behaviors of an individual (in this context, knowledge worker as a unit of analysis in this study) engaged in at each stage of the innovation process. This model outlines the discrete tasks involved in innovation as (a) idea generation and activation of the drivers of the innovation; (b) coalition building and acquisition of the power necessary to move the idea into reality; (c) idea realization and innovation production, turning the idea into a model-a product or plan or prototype that can be implemented; (d) transfer or diffusion, the spreading of the model-the commercialization of the product, the adoption of the idea. The multistage process view indicates that some aspects of organizational innovation are clearly an individual level activities, beginning with idea generation at the first stage. However, individual level activities are not limited to this first phase. In concurrence with Scott and colleagues (Scott \& Falcone, 1998; Scott, 1993), this study adopts the perspective that innovative work behavior involves the full range of behaviors that an individual may exhibit through all of the stages of innovation. Moreover, when studying the effects of determinants on innovative work behavior, most researchers will collapse the suggestion and implementation of ideas into a single measure (Scott \& Bruce, 1994).

\subsection{Leader-Member Exchange and Innovative Work Behavior}

Based on the LMX theory when high-quality relationships exist between the subordinates and superiors, subordinates will be awarded with greater resources and freedom in making decisions (Pelz \& Andrews, 1966; Cotgrove \& Box, 1970). Availability of resources, time and freedom are indeed essential in generating and testing of innovative ideas (Kanter, 1988) and increases the chances the chances of success of innovative work behavior (Yuan \& Woodman, 2010). The confidence towards the value of innovative work behavior in performance and efficiency gains is developed when there is high-quality relationships exist between superiors and subordinates (Yuan \& Woodman, 2010). The importances of how employees perceived they have been rewarded have found to have an effect on their innovative work behavior. When workers perceived that leaders have fairly rewarded them, they tend to respond more innovatively in a higher level of job demand situation (Janssen, 2000). The findings are further supported by the study of Janssen and Van Yperen (2004) among 170 employees in an energy supplier and found a positive impact of LMX on innovative work behavior.

This resulting outcome occurs simply because employees view the existence of distribution equity with regards to the rewards thus encouraging them to engage in innovative work behavior greater (Sanders, Moorkamp, Torka, 
Groenveld, \& Groenveld, 2010). Organizations are characterized by employees since employees are the dominant entity and involved in all activities in organizations and supervisors are viewed as the direct agent of organizations (Sanders et al., 2010). Therefore any actions of the supervisor are viewed as the actions of the organization of the employees (Eisenberger, Huntington, Hutchinson, \& Sowa, 1986) and they will engage in expected behavior as a reward for those actions of the supervisor were deemed to be favorable (Sanders et al., 2010). Thus, we would like to hypothesize that:

Hypothesis 1: LMX has a significant positive relationship with the IWB of knowledge workers in KIBS.

\subsection{Social Capital and Innovative Work Behavior}

Many researchers have shown interest in the concept of social capital (Alguezaui \& Filieri, 2010). The term SC was first coined by Hanifan (1916) in a study on democracy and development of urban community sustainability (Alguezaui \& Filieri, 2010) in which SC is seen as a form of network that was created among the communities which helps in improving the living conditions of everyone in the community. Among the definition of SC in the modern contemporary literature, SC has been defined by Cohen and Prusak (2001) as a social relation-working network (internal and external) that is bounded by mutual trust, understanding, support, and shared values and behaviors to enable innovative collaboration. Nahapiet and Ghoshal (1998) classified social capital into three clusters or dimensions, namely the structural dimensions, the relational dimensions, and the cognitive dimensions. However, the three dimensions within social capital are highly interrelated; as such they can be measured as one dimension (Liao \& Welsch, 2005).

External contacts are necessary in order to make an informed decision on the type of service to be produced as well as to keep updated on the latest trends and development (Kline \& Rosenberg, 1986). Consequently, getting in touch with client regularly is obligatory as to maintain good connections with people from outside (Davison, Watkins, \& Wright, 1989). Furthermore, the success of service deliverance has been frequently the result of high interactions which will provide guidance and recommendations from clients and contacts (Johne \& Storey, 1998). Given such conditions, it is likely that some workers in an organization may have high contacts with the external entities while others may not be so due to the nature of due to the differences in the nature of their job (Jong, Hartog, \& Zoetermeer, 2003). Therefore, in KIBS, it is essential for workers to participate in a high networking activities such attendance to conferences, training and education so that they keep themselves updated with the latest development in their field of work This is important because the greater the external contacts that workers have, the higher the chances for them to engage in innovative work behavior (Jong et al., 2003). Hence, drawing on past literatures, we would like to hypothesize that:

Hypothesis 2: SC has a significant positive relationship with the IWB of knowledge workers in KIBS

\section{Methodology}

Data was collected using the mail survey method. The measurement of this study was adapted from several sources. Based on the previous literatures, the IWB was measured using Janssen's (2000) which had a reported Cronbach's alpha value of .89 while Liden and Maslyn' (1998) measurement was used to measure the LMX and the measurement had a reliability of .90. Finally, SC was measured using Heydebreck's (1997) scale which had a .85 for its Cronbach's alpha value. In Malaysia, there are approximately 40,000 workers serve in the 2,433 of the Multimedia Super Corridor (MSC) status companies (MDEC, 2011). Using Krejcie and Morgan's (1970) table for sampling, the size of the sample appropriate for a population of 40,000 workers is 380 people. The sample obtained for this study was collected using the systematic simple random sampling approach in which a sample was selected randomly at the start of the process and then followed by selecting every Kth element in succession from the available sampling frame (Hair, Black, Babin, Anderson, \& Tatham, 2006) until the targeted sample size is attained.

\section{Results}

Approximately 1520 questionnaires were mailed to those workers in the MSC status companies and from this 355 respondents responded to the survey. Nevertheless, given that there some returned questionnaire contained non-response items, only 318 completely answered questionnaires were used for further analysis. Consequently, the response rate for this study is $20.9 \%$ in line with the prevailing response rate of mail survey found in Malaysia which falls in between $10 \%$ to $20 \%$ (Ramayah, Yan, \& Sulaiman, 2005). The data in this study were analyzed using SPSS 18.0. Factor analysis was carried out to test the construct validity of this study. The factor analysis was preceded by the Kaiser-Meyer-Olkin (KMO) measure of sampling adequacy and the Bartlett's Test of Sphericity. A KMO values which are greater than .60 (Coakes, Steed, \& Ong, 2009), and a large and significant Bartlett's test $(\mathrm{p}<0.05)$ (Hair et al., 2006) would indicate factorability. A factor loading of .30 for each 
item will be accepted to represent a factor based the threshold value to meet the minimal level for interpretation of the structure (Sekaran, 2003; Hair et al., 2006). Additionally factor loading that is greater than .60 is regarded as high while those that is greater than .30 is treated as moderately high (Kline, 1994).

The result of factor analysis for IWB can be seen from Table 1. The table shows that all 9 items were loaded onto a single factor with an eigenvalue of more than 1.0 and the extractions explain $58.82 \%$ of the variance. At the same time, there is a good correlation between the items and the factor grouping that they belong to given that all the items have a loading of greater than .60 .

Table 1. Summary of factor loadings for IWB

\begin{tabular}{ll}
\hline Questions & Component \\
& 1 \\
\hline IBW1 I create new ideas for difficult issues & .815 \\
IWB2 I search out new technologies, processes, working methods, techniques, and/or & .772 \\
product ideas. & .623 \\
IWB3 I generate original solutions for problems. & .618 \\
IWB4 I mobilize support for innovative ideas. & .776 \\
IWB8 I introduce ideas into the work environment in a systematic way. & .703 \\
IWB9 I evaluate the utility (benefits) of innovative idea. & .679 \\
IWB7 I transform innovative ideas into useful applications. & .813 \\
IWB5 I make organizational members enthusiastic for innovative ideas. & .649 \\
IWB6 I try to acquire approval for innovative ideas. & \\
Eigenvalues & \\
Percentage of variance explained $=58.82 \%$ & 5.294 \\
KMO= 0.645 & \\
Bartlett's Test of Sphericity : & \\
Approx Chi-square = 493.700 & \\
df $=36$ & \\
Sig $=.000$ &
\end{tabular}

Table 2 shows the result of the factor analysis of leader-member exchange. All 13 items were found to be greater than 0.6 indicating a good correlation between the items and the factor grouping they belong. The percentage of total variance explained is $69.97 \%$ and the items have a single factor extraction.

Table 2. Summary of factor loadings for LMX

1

LMX 4 My supervisor/manager defends my work actions to a superior, even without ${ }^{7}{ }^{725}$ complete knowledge of the issue in question.

LMX 3 My supervisor/manager is a lot of fun to work with.

LMX 11 I respect my supervisor/manager's knowledge of and competence on the job. .659

LMX 6 My supervisor/manager would defend me to others in the organization if I made ${ }^{803}$ an honest mistake.

LMX 5 My supervisor/manager would come to my defense if I were "attacked" by .714 others. 
1

LMX 7 I do work for my supervisor/manager that goes beyond what is specified in my ${ }^{.701}$ job description.

LMX 8 I am willing to apply extra efforts, beyond those normally required, to further ${ }^{.791}$ the interests of my work group.

LMX 9 I have enough confidence in my supervisor/manager that I would defend and ${ }^{777}$ justify his/her decision if he/she were not present to do so.

LMX 10 I am impressed with my supervisor/manager's knowledge of his/her job. $\quad .528$

LMX 13 My supervisor(s) encourages me to share knowledge. $\quad .830$

LMX 12 I admire my supervisor/manager's professional skills.

LMX 2 My supervisor /manager is the kind of person one would like to have as a friend..820

LMX1 I like my supervisor/manager very much as a person. $\quad .816$

Eigenvalues

Percentage of variance explained $=69.97 \%$

$\mathrm{KMO}=0.669$

Bartlett's Test of Sphericity :

Approx Chi-square $=1160.313$

$\mathrm{df}=78$

Sig $=.000$

Table 3 on the other hand shows the result of the factor analysis of the SC variable. All the 12 questions were loaded into a single factor with eigenvalue of more than 1.0. The percentage of variance explained is $70.39 \%$. The factor loadings have all found to be greater than 0.6 thus indicating good correlation between the items and the factor grouping they belong to.

Table 3. Summary of factor loadings for SC

\section{Component}

1

SC 7 My organization has effective policies and procedures for knowledge sharing in ${ }_{.787}$ place.

SC 8 My organization has trainings and workshops that focus around sharing .716 knowledge.

SC 6 In my organization, senior management models the knowledge sharing behaviors they want to see.

SC 2 I have frequent contacts with suppliers of my company.

SC 1 I have frequent contacts with the customers of our company.

SC 4 I always perceived my colleagues as important sources of professional advice, when I have a work-related problem, or when I want advice on a decision that I have.758 to make.

SC 5 I always perceived my colleagues as a group of person that I can count on, whom .709 I view as allies, and who are dependable in times of crisis (support).

SC 3 I often talk to other professionals from other companies in our industry.

SC 10 My organization uses organizational learning to support existing core .778 competencies and create new ones. 


\section{Component}

1

SC 9 My organization has a company-wide social events which provide opportunities ${ }^{7} 758$

for knowledge sharing.

SC 12Knowledge sharing is linked to employee advancement.

.865

SC 11My organization provides me with the time and resources to share knowledge. $\quad .816$

Eigenvalues

Percentage of variance explained $=70.39 \%$

$\mathrm{KMO}=0.560$

Bartlett's Test of Sphericity :

Approx Chi-square $=927.541$

$\mathrm{df}=66$

Sig $=.000$

The measurements were re-tested for reliability after the process of extractions. This is to ensure the existence of internal consistencies of the measurements after factor analysis has been carried out. The result of the analysis shows the existence of internal consistency ranging from .67 for IWB to .78 for LMX while SC has reliability value of .66 which have met the threshold value of at .60 as suggested by Hair et al. (2006). Table 4 shows the reliability statistic for the measurement based on past literatures and the current study.

In terms of respondents' profile, the analysis reveals that $53.2 \%$ of the respondents are males while the remaining $46.8 \%$ are females. The majority of them were from first degree holders $(55.5 \%)$, followed by postgraduate degree holders $(30.6 \%)$ and finally diploma holders $(13.9 \%)$. In terms of sub-sector contribution, most of the respondents are those working in the shared services and outsourcing comprised of $22.3 \%$ while the least number of respondents came from the hardware design sector of $4.8 \%$.

Table 4 shows the result of the inter-correlation between the variables. The bivariate correlation test revealed that LMX and IWB have a positive significant relationship with IWB ( $\mathrm{r}=0.406, \mathrm{p}<.01)$. Similarly, SC also has a positive significant relationship with the IWB of the employees of the KIBS sector $(r=.436, p<.01)$. Based on the outcome of the correlation analysis, there are insufficient evidences to reject both $\mathrm{H} 1$ and $\mathrm{H} 2$.

Table 4. Correlation matrix of the variables

\begin{tabular}{lllll}
\hline & Variables & IWB & LMX & SC \\
\hline 1 & IWB & 1.000 & & \\
2 & LMX & $.406^{* *}$ & 1.000 & \\
3 & SC & $.436^{* *}$ & $.586^{* *}$ & 1.000
\end{tabular}

Note: $* *$ Correlation is significant at the 0.01 level (2-tailed)

Table 5 shows the result of the multiple regression analysis. A multiple regression analysis was carried out in order to determine which predictor has a stronger influence on the employee IWB. Result from the multiple regression analysis revealed a value of $\mathrm{R} 2$ of $22.5 \%$. This value of $\mathrm{R} 2$ shows that $22.5 \%$ of the variance in the employee IWB can be explained by the two predictors in this study specifically LMX and SC. Additionally, in order to determine the strength of the influence between the predictors towards IWB, a reference to the standard beta value is made. This study reveals that SC has as a stronger influence on the IWB as compared to LMX. This is evidenced in the higher beta value for $\mathrm{SC} \beta=.302$ compared to $\beta=.229$ for LMX. Closer inspection of Table 5 also shows there is a significant positive regression weight for both LMX and SC which indicates that when LMX and SC are in existence, the IWB of employees can be enhanced. Thus both variables contribute to the regression model and $\mathrm{HI}$ and $\mathrm{H} 2$ are accepted. The research model is also free from the multicolinearity problem which is indicated by a low VIF value of less than 10 (Hair et al., 2006). 
Table 5. Multiple regressions of LMX, SC and IWB

\begin{tabular}{llllllll}
\hline Independent & \multicolumn{9}{l}{ IWB (Dependent Variable) } & & & \\
Variables & Beta & Std Error & Std Beta & $\mathrm{t}$ & $\mathrm{Sig}$ & Tolerance & VIF \\
\hline (Constant) & 2.556 & .320 & & 7.996 & .000 & & \\
LMX & .219 & .059 & .229 & 3.697 & .000 & .656 & 1.524 \\
$\mathrm{SC}$ & .323 & .066 & .302 & 4.867 & .002 & .656 & 1.524 \\
$\mathrm{R}$ & 474 & & & & & & \\
$\mathrm{R}^{2}$ & 0.225 & & & & & & \\
$\mathrm{~F}$ & 44.547 & & & & & & \\
Sig & 0.000 & & & & & & \\
\hline
\end{tabular}

\section{Conclusions and Implications}

This study has been carried out with the aim to find evidence on whether the IWB of employees working in the KIBS sector can be influenced by LMX and SC at their workplace. This study was meant to fill up the gap and lack of studies on individual innovative behavior especially in the context of KIBS in Malaysia. Even though there were many past researches (e.g. Mohamed, 1995; Jantan et al., 2003; Ishak, 2005; Khairuzzaman \& Majid, 2007; Idris, 2008; Ghani et al., 2009; Ibrahim et al., 2009) on innovation were conducted in Malaysia, none of them had conducted the study in KIBS or had addressed the aspect of behavioral innovation of the knowledge workers in Malaysia. Thus, this study contributes to the current literatures on KIBS, innovative work behavior and knowledge workers which are generally quite limited in Malaysia. This study has thus provided insights into the KIBS sector that has received little attention and probably a term that may not be familiar among researchers in Malaysia. It is hoped that this study is able to pave ways for more future researches to take on similar studies perhaps by looking at the other possible variables that may expand on this research model. The above results reveal that both LMX and SC have a significant positive relationship with the IWM employees in the KIBS sector. The importance of LMX on employees' IWB resulted in them responded more innovatively to higher levels of job demands when they perceived that their efforts were fairly rewarded by their leader Janssen (2000). Further, the trust inherent in high LMX relationship provides a context in which subordinates are more comfortable suggesting and promoting innovative ideas. At the same time, social capital plays a significant positive role in influencing the development of both incremental and radical innovation (Subramaniam \& Youndt, 2005). Through socialization, knowledge workers share their intricate technical experiences and mental models of common interest with each other through observation, practice, and imitation. Socialization outside the workplace and with members of other organizations is also beneficial. It increases the trust, opportunity, and the motivation to engage in knowledge sharing (Oh et al., 2004).

One of the major obstacles for employees not to innovate could due to the fear that their action might be perceived negatively by others. Thus, it is necessary for managers to put greater emphasize on the importance of innovation and embedded the idea as part of the job requirements would certainly help innovative behavior to flourish in the workplace. Employees have to understand that innovation does not only result in the R\&D departments and managers would have an important mission to overcome this mindset barrier and to elucidate behavioral innovation among these workers. This is to prevent them from alienating innovation in their day to day job since thinking that they are dealing with non-technology types of job.

Given that the variables chosen in this study were also widely studied as the drivers of innovation in most manufacturing and service based companies in general, it is suggested that other predictors can be considered when in future studies to extend the list of predictors of IWB. This study has also collapsed the multistage of innovative work behavior as suggested by Scott and Bruce (1994). This is somehow limiting the ability to obtain a broader understanding on the influence of the predictors on various stages of IWB as discussed by Kanter's (1988) model. Furthermore a low R2 value of $22.5 \%$ as shown in this study may have also indicated that there is a need to investigate on other possible predictors of IWB. Previous studies have shown that some personal characteristics tend to may have influence on innovative behaviors. Among others, factors such as tolerance towards ambiguity and uncertainty, the desire for stability, self-confidence and independence (Nicholson \& West, 1988; Rushton \& West, 1988) can be considered in the future to add richness to the present study of the KIBS sector. 


\section{References}

Alguezaui, S., \& Filieri, R. (2010). Investigating the role of social capital in innovation: Sparse versus dense $\begin{array}{lllll}\text { network. Journal of Knowledge } & \text { Management, }\end{array}$ http://dx.doi.org/10.1108/13673271011084925

Aselage, J., \& Eisenberger, R. (2003). Perceived organizational support and psychological contracts: A theoretical integration. Journal of Organizational Behavior, 24, 491-495. http://dx.doi.org/10.1002/job.211

Basu, R., \& Green, S. G. (1997). Leader-member exchange and transformational leadership: An empirical examination of innovative work behaviors in leader-member dyads. Journal of Applied Social Psychology, 27(6), 477-499. http://dx.doi.org/10.1111/j.1559-1816.1997.tb00643.x

Bessant, J. (2003). Challenges in innovation management. In L. V. Shavinina (Ed.), The international handbook on innovation (pp. 761-774). Oxford, UK: Elsevier. http://dx.doi.org/10.1016/B978-008044198-6/50052-8

Bilderbeek, R., Hertog, P., Marklund, G., \& Miles, I. (1998). Services in Innovation: Knowledge Intensive Business Services (KBIS) as co-producers of innovation. SI4S Synthesis Paper No. 3, STEP Group Oslo.

Blau, P. M. (1964). Exchange and power in social life. New York: Wiley.

Bolino, M. C., Turnley, W. H., \& Bloodgood, J. M. (2002). Citizenship behavior and the creation of social capital in organizations. Academy of Management Review, 27, 505-522

Burt, R. S. (1992). Structural holes. Cambridge, MA: Harvard University Press.

Coakes, S. J., Steed, L., \& Ong, C. (2009). SPSS 16.0 for windows: Analysis without anguish. Australia: John Wiley \& Sons.

Cohen, D., \& Prusak, L. (2001). How to invest in social capital. Harvard Business Review, 79(6), 86-93.

Coleman, J. S. (1990). Foundations of social theory. Cambridge, MA: Harvard University Press.

Cotgrove, S., \& Box, S. (1970). Science, industry, and society: Studies in the sociology of science. London: George Allen \& Unwin.

Damanpour, F. (1991). Organizational innovation: A meta-analysis of effects of determinants and moderators. Academy of Management Journal, 34, 555-590. http://dx.doi.org/10.2307/256406

Damanpour, F., Szabat, K. A., \& Evan, W. M. (1989). The relationship between types of innovation and organizational performance. Journal of Management Studies, 26(6), 587-601. http://dx.doi.org/10.1111/j.1467-6486.1989.tb00746.x

Davison, H., Watkins, T., \& Wright, M. (1989). Developing new personal financial products-some evidence on the role of market research. International Journal of Bank Marketing, 7(1), 8-15. http://dx.doi.org/10.1108/02652328910134563

Economic Planning Unit (EPU). (2009). Knowledge content in key economic sectors in Malaysia phase. Putrajaya: Percetakan Nasional Malaysia Bhd.

Eisenberger, R., Huntington, R., Hutchinson, S., \& Sowa, D. (1986). Perceived organizational support. Journal of Applied Psychology, 71, 500-507. http://dx.doi.org/10.1037/0021-9010.71.3.500

Ghani, N. A. A., Hussin, A. B. S. R., \& Jusoff, K. (2009). Antecedents of psychological empowerment in the Malaysian private higher education institutions. Internal Education Studies, 2(3), 1616.

Hair, J. F., Black, W. C., Babin, B. J., Anderson, R. E., \& Tatham, R. L. (2006). Multivariate data analysis (6th ed.). New Jersey: Prentice Hall.

Hanifan, L. J. (1916). The rural school community center. Annuals of the American Academy of Political and Social Science, 67, 130-138. http://dx.doi.org/10.1177/000271621606700118

Heydebreck, P. (1997). Technological interweavement: A means for new technology-based organizations to achieve innovation success. London: Macmillan.

Homans, G. C. (1958). Social behavior as exchange. American Journal of Sociology, 63(6), 31-41. Retrieved from http://dx.doi.org/10.1086/222355

Ibrahim, A. R., Zolait, A. H. S., Subramanian, S., \& Ashtiani, A. V. (2009). Organizational innovative capabilities: An empirical study of Malaysian firms. Journal of Innovation and Business Best Practices, l(2), 9-18.

Idris, A. (2008). Cultivating innovation through female leadership: The Malaysian perspective. Asian Social 
Science, 4(6), 3-10.

Ishak, N. A. (2005). Promoting employees' innovativeness and organizational citizenship behavior through superior-subordinate relationship in the workplace. Research and Practice in Human Resource Management, 13(2), 16-30.

Janssen, O. (2000). Job demands, perceptions of effort-reward fairness, and innovative work behavior. Journal of Occupational and Organizational Psychology, 73, 287-302. http://dx.doi.org/10.1348/096317900167038

Janssen, O., \& Van Yperen, N. W. (2004). Employees' goal orientations, the quality of leader member exchange, and the role of job performance and job satisfaction. Academy of Management Journal, 47(3), 368-384. http://dx.doi.org/10.2307/20159587

Jantan, M., Nasurdin, A. M., \& Fadzil, N. F. A. (2003). Designing innovative organizations in Malaysia: Do structure and culture matter? Global Business Review, 4(2), 213-226. http://dx.doi.org/10.1177/097215090300400201

Jarman, J., \& Chopra, P. S. (2008). Business services and the knowledge economy in Malaysia. International Journal of Sociology and Social Policy, 28(5/6), 93-203. http://dx.doi.org/10.1108/01443330810881240

Johne, A., \& Storey, C. (1998). New service development: A review of literature and annotated bibliography. European Journal of Marketing, 32(3), 184-251. http://dx.doi.org/10.1108/03090569810204526

Jong, J., Hartog, D., \& Zoetermeer. (2003). Leadership as determinant of innovative behavior: A conceptual framework. Research Report H200303, 1-95.

Kanter, R. M. (1988). When a thousand flowers bloom: Structural, collective and social conditions for innovation in organization. Research in Organizational Behavior, 10, 169-211.

Kassim, H. (2009). Innovation, $R \& D$ and technology. NEAC Paper, 3/2, 1-20.

Kline, P. (1994). An easy guide to factor analysis. London: Routledge.

Kline, S. J., \& Rosenberg, N. (1986). An overview of innovation. In R. Landau, \& N. Rosenberg (Eds.), The Positive sum strategy: Harnessing technology for economic growth (pp. 275-305). Washington D.C.: National Academy Press.

Krejcie, R., \& Morgan, D. (1970). Determining sample size for research activities. Educational and Psychological Measurement, 30, 607-610.

Liao, J., \& Welsch, H. (2005). Roles of social capital in venture creation: Key dimensions and research implications. Journal of Small Business Management, 43(4), 345-362. http://dx.doi.org/10.1111/j.1540-627X.2005.00141.x

Liden, R. C., \& Maslyn, J. M. (1998). Multidimensionality of leader-member exchange: An empirical assessment through scale development. Journal of Management, 24, 43-72.

Lin, N. (2001). Building a network theory of social capital. In K. C. A. R. B. N. Lin (Ed.), Social capital, theory and research (pp. 3-29). New York: Aldine de Gruyter.

Malaysian Institute of Economic Research (MIER). (2009). Services the next growth engine? Retrieved March 10, 2011, from http://www.mier.org.my

Meriam, I. (2006). Creative climate and learning culture: Their contributions towards innovation within a property developer organization. Journal for the Advancement of Science \& Arts, 1, 22-28.

Miles, I., Kastrinos, N., Bilderbeek, R., den Hertog, P., Flanagan, K., \& Huntink, W. (1995). Knowledge-intensive business services: Their role as users, carriers and sources of innovation. Report to the EC DG XIII, Luxembourg: Sprint EIMS Programme.

Mohamed, M. Z. (1995). Innovation implementation in Malaysian organizations: Process, problems, critical success factors and working climate. Technovation, 15(5), 375-385. http://dx.doi.org/10.1016/0166-4972(95)96598-N

Multimedia Development Corporation (MDeC), Malaysia. (1999). Retrieved February 11, 2011, from http://www.msc.com.my

Nahapiet, J., \& Ghoshal, S. (1998). Social capital, intellectual capital, and the organizational advantage. Academy of Management Review, 23(2), 242-266.

Nicholson, N., \& West, M. A. (1988). Managerial Job Change: Men and Women in Transition. Cambridge: Cambridge University Press. http://dx.doi.org/10.1017/CBO9780511522116

Nystrom, H. (1990). Organizational innovation. In M. A. West, \& J. L. Farr (Eds.), Innovation and creativity at 
work: Psychological and organizational strategies (pp.143-161). Chichester: John Wiley \& Sons Ltd.

Oh, H., Myung-Ho, C., \& Labianca, G. (2004). Group social capital and group effectiveness: The role of informal socializing ties. Academy of Management Journal, 47, 860-875. http://dx.doi.org/10.2307/20159627

Organ, D. W. (1988). Organizational citizenship behavior: The good soldier syndrome. Lexington, MA: Lexington Books.

Pelz, D. C., \& Andrews, F. M. (1966). Autonomy, coordination, and stimulation in relation to scientific achievement. Behavioral Science, 11, 89-97. http://dx.doi.org/10.1002/bs.3830110202

Ramayah, T., Yan, L. C., \& Sulaiman, M. (2005). SME e-readiness in Malaysia: Implications for planning and implementation. Sasin Journal of Management, 11(1), 103-120.

Razmi, C., \& Hazman, S. A. (2002). A study of the senior managers' perception of innovation management in a large multi-business conglomerate. Malaysian Management Review, 37(1), 53-66.

Rushton, R., \& West, M. A. (1988). Mismatches in Work Role Transitions. MRC/ESRC Social and Applied Psychology Unit, University of Sheffield, Memo Number 983.

Sanders, K. S., Moorkamp, M., Torka, N., Groenveld, S., \& Groenveld, C. (2010). How to Support Innovative work behavior? The role of LMX and satisfaction with hr practice. Technology and Investment, 1, 59-68. http://dx.doi.org/10.4236/ti.2010.11007

Scott, P. G., \& Falcone, S. (1998). Comparing public and private organizations: An exploratory analysis of three frameworks. American Review of Public Administration, 28(2), 126-145. http://dx.doi.org/10.1177/027507409802800202

Scott, S. G. (1993). The influence of climate perceptions of innovative work behavior: A model of individual innovation in the workplace. (Unpublished doctoral dissertation). University of Cincinnati, Cincinnati, $\mathrm{OH}$.

Scott, S. G., \& Bruce, R. A. (1994a). Determinants of innovative work behavior: A path model of individual innovation in the workplace. Academy of Management Journal, 38, 1442-1465.

Sekaran, U. (2003). Research methods for business: A skill building approaches (4th ed.). New York: John Wiley \& Sons Inc.

Subramaniam, M., \& Youndt, M. A. (2005). The influence of intellectual capital on the types of innovative capabilities. Academy of Management Journal, 48, 450-463. http://dx.doi.org/10.5465/AMJ.2005.17407911

Tovstiga, G. (1999). Profiling the knowledge workersin the knowledge intensive organization: Emerging roles. International Journal of Technology Management, 18(5-8), 731-744.

Wan Khairuzzaman, W. I., \& Majid, R. A. (2007). Framework of the culture of innovation: A revisit. Journal Kemanusiaan, 9, 38-49.

West, M. A., \& Farr, J. L. (1990). Innovation at work. In M. A. West, \& J. L. Farr (Eds.), Innovation and Creativity at Work: Psychological and Organizational Strategies (pp. 3-13). Chichester: Wiley.

Wheelwright, S. C., \& Clark, K. B. (1995). Leading product development: The senior manager's guide to creating and shaping the enterprise. New York: Free Press.

Yeoh, K. K., Mahmood, R., \& June, S. (2013). A Conceptual Review of Innovative Work Behavior in Knowledge Intensive Business Services among Knowledge Workers in Malaysia. International Journal of Business, Humanities and Technology, 3(2), 91-99.

Yuan, F., \& Woodman, R. W. (2010). Innovative work behavior in the workplace: The role of performance and image outcome expectations. Academy of Management Journal, 53(2), 323-342. http://dx.doi.org/10.5465/AMJ.2010.49388995

Yukl, G. A. (2006). Leadership in organizations (6th ed.). Upper Saddle River, NJ: Prentice Hall.

\section{Copyrights}

Copyright for this article is retained by the author(s), with first publication rights granted to the journal.

This is an open-access article distributed under the terms and conditions of the Creative Commons Attribution license (http://creativecommons.org/licenses/by/3.0/). 